American Journal of Environmental Sciences 8 (1): 35-41, 2012

ISSN 1553-345X

(C) 2012 Science Publications

\title{
Genetic Diversity in Cichla monoculus (Spix and Agassiz, 1931) Populations: Implications for Management and Conservation
}

\author{
Carlos Henrique Dos Anjos Dos Santos, Carolina Fernandes Silva De Sousa, \\ Maria de Nazare Paula-Silva, Adalberto Luis Val and Vera Maria Fonseca De Almeida-Val \\ Department of Ecology, Laboratory of Ecophysiology and Molecular Evolution, \\ National Institute for Research in the Amazon, 69060-001, Manaus, Brazil
}

\begin{abstract}
Problem statement: The object of this study was to examine the genetic structure and gene flow in Cichla monoculus populations in seven varzea lakes of the Solimoes River using Randomly Amplified Polymorphic DNA (RAPD) markers, to monitor the region where petroleum is transported in the Amazon basin. Approach: The loss of genetic diversity is one of the main factors leading to reduced evolutionary potential in species of fish. In this context, this paper seeks to understand how the influence of the stretch of pipeline in the Solimoes River between the cities of Manaus-Coari influences the genetic structure of $C$. monoculus. For this we measured the level of genetic diversity and structure of the species in the studied stretch. Results: Proportions of polymorphic loci varied from $8.7-39.7 \%$ in analyzed populations. Low heterozygosis levels were detected $(\mathrm{He}=0.1652)$ and highly structured populations in the seven lakes with low gene flow $(\mathrm{Nm}=0.7025)$ among all fish studied. Unexpected differentiation was found between fishes among the lakes. Fish populations from lakes closest to Manaus (human population of $\sim 2$ million) are different from those occurring in lakes closest to the Coari region (close proximity to petroleum barge transfer terminals). Conclusion/Recommendations: Differentiation can be explained by natural causes. This study identifies antropogenic activities influencing this species overall. Since industrial fishing is prevalent due to the high economic value of $C$. monoculus. Also, this species posses behavioral characteristics that are desirable in sports fishing. Management and conservation of this species will be necessary in the near future to recover genetic variability levels in each lake and allow gene flow among them. Further studies are needed to better understand the differentiation among populations.
\end{abstract}

Key words: Amazon basin, tucunare populations, Cichla monoculus, varzea lakes, high economic value, genetic studies, sports fishing, genetic distance, skeletal muscle, peacock bass, artificial fish populations

\section{INTRODUCTION}

The Cichlidae is one of the most diverse families of teleost fish and is widely distributed in tropical ecosystems. Most of its representatives are found in fresh water environments (Andrade et al., 2001). According to Carvajal et al. (2005), the species of this family are found in clear, dark and white water rivers. Among all species of neotropical cichlids, the Cichla spp (tucunarés) are considered the biggest (Nelson, 2006), which results in a great commercial importance, both as food item and as an important sports fishing species (Jepsen et al., 1997).

Cichla monoculus (tucunaré) occurs in the Amazon Basin (Sampaio et al., 2000). It is a non-migratory species adapted to lentic environments (Farias et al.,
2005, Petrere, 1996). It is a territorial species with seasonal spawning and broth mouthing habits, contributing to their aggressive behavior fish, particularly when taking care of their offspring (Nelson, 2006). According to Kullander and Ferreira (2006) there are 24 species of Cichla; however, only five of them are accepted and considered valid by the taxonomists: C. temensis, C. monoculus, C. ocellaris, C. orinocensis and C. intermedia.

Despite its importance to the local economy, recreational activities often supports the local economy there are few genetic studies about tucunaré populations in its natural environment. Studies on genetic variability addressing natural and artificial fish populations are of great importance to understand how variations in survival, reproduction and growth rates

Corresponding Author: Carlos Henrique Dos Anjos Dos Santos, Department of Ecology, Laboratory of Ecophysiology and Molecular Evolution, National Institute for Research in the Amazon, 69060-001, Manaus, Brazil Tel: +55 (92) 3643-3188 
Am. J. Environ. Sci., 8 (1): 35-41, 2012

contribute to alterations in gene and genotypic frequencies and vice versa.

Several methods are available to analyze genetic variability in natural fish populations. After the $1950^{\text {ce }} \mathrm{s}$, when electrophoresis was first used for protein separation, protein based markers (isozymes) became one of the first methodologies applied to investigate genetic variability in populations. Isozyme (product of gene duplication) and allozyme (product of gene mutation) systems were largely used in the 1980's to detect genetic variability and estimate genetic distance among related species. Once few uniloci bands were found in many enzyme systems, it also became a powerful tool to investigate genetic polymorphism in different populations (Parker et al., 1998). Thus, proteins have been used in phylogenetic studies (Tringali et al., 1999) and also in studies about population variability of many fish species (Calcagnotto and Toledo-Filho, 2000). More recently, the Random Amplification of Polymorphic DNA (RAPD) has been described and used in similar studies. RAPD was the first genomic DNA based marker (Williams et al., 1990) and has been widely applied during the past years. The RAPD technique has been an achievement in quick estimating values of genetic diversity between populations, species and fish lineages (Povh et al., 2005). Nowadays, although many new molecular markers are available, RAPD remains the most rapid and economically viable tool to access genetic variability in populations and establish further planning for management and conservation programs.

In Amazon region, the Urucu petroleum province contains a vast reserve of petroleum and natural gas. This reserve has been explored by Brazilian government since early 1980's. The area studied in the present work includes varzea lakes that are under direct influence of the main river (Solimoes River) floating system. This region is under environmental pressure since it is the main area of petroleum and gas transportation in the Amazon; petroleum and gas extracted from Urucu petroleum basin is transferred from the main platform to a terminal in Solimoes River by pipelines. From the Solimoes Terminal (TESOL), which is located in the vicinity of Coari town, the petroleum and gas are transported in barges to the refinery plant, located in the city of Manaus. The river margins can be damaged (by erosion) by the movement of the barges and there is always the risk of an oil spill. These environmental threats increase during low water level season.

The objective of this study is to investigate the genetic integrity of $C$. monoculus (Tucunaré) populations that occur in seven varzea lakes along Solimoes River between the cities of Coari and Manaus, using RAPD.

\section{MATERIALS AND METHODS}

Sample tissue collection and digestion: A total of 57 individuals of $C$. monoculus were collected in seven "varzea" lakes along Solimoes River (Table 1 and Fig. 1). All collections were done during the expeditions of the Network PIATAM, phases III and IV (funded by PETROBRAS and FINEP). Tissue samples were extracted immediately after fish collection. Frozen tissue samples of skeletal muscle were kept in liquid nitrogen containers during boat trips and transferred to$80^{\circ} \mathrm{C}$ freezers in the laboratory at INPA research facilities. These samples were used for DNA extractions. Tissue samples were digested in sterile Eppendorf tubes containing $5 \mu \mathrm{L}$ digestive solution ( $\mathrm{NaCl} 0.4 \mathrm{M}$, EDTA 0.1 M pH 8.0, Proteinase K 100 $\mu \mathrm{g} \mathrm{mL} \mathrm{m}^{-1}$, SDS $0.1 \%$ ) and RNAse enzyme (100 mg $\left.\mathrm{mL}^{-1}\right)$. The tubes were shaken gently and incubated at $60^{\circ} \mathrm{C}$ for, at least, two hours. After tissue digestion, DNA extraction was preceded.

Genomic DNA extraction: Both tissue digestion and DNA extraction were performed according to the methodology described in Sambrook and Russel (2001) DNA extraction followed with the addition of 600 phenol-chloroform to the Eppendorf tubes, to dissolve any remains of proteins. Tubes were then centrifuged (MPW-Med. Instruments, model MPW-350R) at $13,000 \times \mathrm{g}$ for $109 \mathrm{~min}$. Dissolved DNA in the buffer solutions was extracted off the top of the phenolchloroform layers, using cut pipette tips rather than the normal uncut tips, to avoid breaking of DNA in the sample. Supernatants were added into new Eppendorf tubes containing $1 \mathrm{ml}$ of cold absolute ethanol for DNA precipitation. Gentle mixing by inverting dissolved any impurities left in the sample, $1 \mathrm{M}$ sodium chloride was added to the DNA in the ethanol and the tubes were frozen at $-80^{\circ} \mathrm{C}$ for $30 \mathrm{~min}$. This step precipitates DNA. After thawing, the tubes were centrifuged for $5 \mathrm{~min}$ and excess ethanol was poured off to leave a small pellet at the bottom of each tube, pellets were washed with 200 cold $70 \%$ ethanol and again centrifuged for $5 \mathrm{~min}$. Ethanol was poured off and the tubes (with pellet at the bottom) were incubated overnight at $37^{\circ} \mathrm{C}$. After evaporation of all excess ethanol, the dried DNA was diluted in $500 \mathrm{TE}$ buffer (TRis- $\mathrm{HCl} 10 \mathrm{mM}$, EDTA 1 $\mathrm{mM}$ ) and stored in Eppendorf tubes at $-20^{\circ} \mathrm{C}$.

To access quality and quantity of DNA, a small aliquot of each sample was run on a $0.8 \%$ agarose minigel in $30 \mathrm{~mL}$ of Tris-Borate-EDTA-buffer (sigma) $\mathrm{pH} 8.3$, stained with 3 ethidium bromide solution (BDH - $10 \mathrm{mg} \mathrm{mL}^{-1}$ ) and assessed under UV light. All gels were run with a known DNA concentration of phage $\lambda(20-40 \mathrm{ng})$. Subsequently the DNA was diluted in $5 \mathrm{ng} \mu \mathrm{L}^{-1}$ for RAPD reactions. 
Am. J. Environ. Sci., 8(1): 35-41, 2012

Table 1: Lakes of the Coari-Manaus section with Latitude and Longitude coordinates

\begin{tabular}{|c|c|c|}
\hline Lakes & Latitude & Longitude \\
\hline Baixio & $03^{\circ} 17^{\prime} 23,4^{\prime \prime} \mathrm{S}$ & $60^{\circ} 04^{\prime} 38,8^{\prime \prime} \mathrm{W}$ \\
\hline Preto & $03^{\circ} 21^{\prime} 17,1^{\prime \prime} \mathrm{S}$ & $60^{\circ} 37^{\prime} 28,6^{\prime \prime} \mathrm{W}$ \\
\hline Iauara & $03^{\circ} 36,39,2^{\prime \prime} \mathrm{S}$ & $61^{\circ} 16^{\prime} 33,0^{\prime \prime} \mathrm{W}$ \\
\hline Ananá & $03^{\circ} 54^{\prime} 44,8^{\prime \prime} \mathrm{S}$ & $61^{\circ} 40^{\prime} 48,6^{\prime \prime} \mathrm{W}$ \\
\hline Campina & $03^{\circ} 45^{\prime} 49,9^{\prime \prime} \mathrm{S}$ & $62^{\circ} 20^{\prime} 45,8^{\prime \prime} \mathrm{W}$ \\
\hline Maracá & $03^{\circ} 50^{\prime} 49,4^{\prime \prime} \mathrm{S}$ & $62^{\circ} 34^{\prime} 32,0^{\prime \prime} \mathrm{W}$ \\
\hline Poraquê & $03^{\circ} 57^{\prime} 49,4^{\prime \prime} \mathrm{S}$ & $63^{\circ} 09^{\prime} 50,9^{\prime \prime} \mathrm{W}$ \\
\hline
\end{tabular}

Table 2: Base pair sequences for RAPD, CG percentages and the obtained loci numbers

\begin{tabular}{lllc}
\hline Primers & Sequences (5'- 3') & \%CG & Loci numbers (NL) \\
\hline H-3 & AGACGTCCAC & 60 & 21 \\
H-4 & GGAAGTCGCC & 70 & 21 \\
H-5 & AGTCGTCCCG & 70 & 21 \\
P-05 & GTGGTCCGCA & 70 & 21 \\
P16 & CCAAGCTGCC & 70 & 21 \\
A132 & AAGAGCCCGT & 60 & 21 \\
Total & & & 126 \\
\hline
\end{tabular}

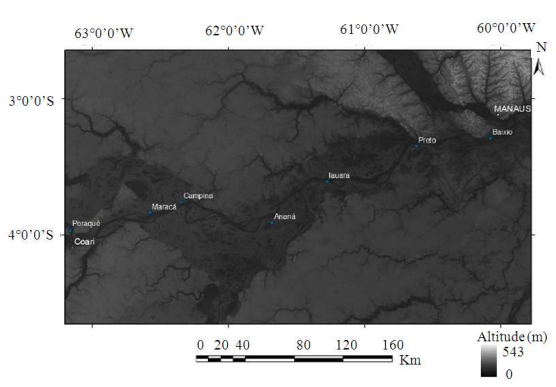

Fig. 1: Location map (Digital Elevation Model) showing topography and the locations of the Solimoes Varzea lakes where fish were collected. The lakes are located between the cities of Manaus and Coari

PCR-RAPD procedure: PCR reactions were performed in 25 total volume containing 2 reaction buffer $(10 \mathrm{mM}$ Tris $-\mathrm{HCl}, \mathrm{pH} 8.5 ; 15 \mathrm{mM} \mathrm{MgCl} 2$, 500mM KCl, 1\% Triton X-100, Dynazyme TM II), 0,2 $\mathrm{mM}(\mathrm{pH}$ 7.0) of each deoxynucleotide triphosphate (dATP, dCTP, dTTP, dGTP), $0.75 \mathrm{mM} 10$-mer primer (Operon), genomic DNA and 11.75 water (molecular biology grade, $\mathrm{BDH}$ ). The reaction mixture was overlaid with 30 mineral oil (Sigma). DNA amplification was performed in a thermal cycler (Applied Biosystems).

The tubes were placed at random in the PCR machine for an initial melting step at $94{ }^{\circ} \mathrm{C}$ for $3 \mathrm{~min}$, before $0.5 \mathrm{U}$ of Taq DNA polymerase (DynazymeTM II) was added. For the first cycle, denaturation was $96^{\circ} \mathrm{C}$ for $3 \mathrm{~min}$, annealing at $37^{\circ} \mathrm{C}$ for $1 \mathrm{~min}$ and extension at $72^{\circ} \mathrm{C}$ for $1.5 \mathrm{~min}$. Denaturation time was decreased to $30 \mathrm{~s}$ for the following 40 cycles. A final extension step at $72^{\circ} \mathrm{C}$ was performed for $3 \mathrm{~min}$ before the samples were finally cooled off at $4^{\circ} \mathrm{C}$. A negative control with template DNA replaced by water, was performed for each set of amplifications, in order to verify the absence of contamination.
The tubes were placed at random in the PCR machine for an initial melting step at $94^{\circ} \mathrm{C}$ for $3 \mathrm{~min}$, before $0.5 \mathrm{U}$ of Taq DNA polymerase (DynazymeTM II) was added. For the first cycle, denaturation was $96^{\circ} \mathrm{C}$ for $3 \mathrm{~min}$, annealing at $37^{\circ} \mathrm{C}$ for $1 \mathrm{~min}$ and extension at $72^{\circ} \mathrm{C}$ for $1.5 \mathrm{~min}$. Denaturation time was decreased to $30 \mathrm{~s}$ for the following 40 cycles. A final extension step at $72^{\circ} \mathrm{C}$ was performed for $3 \mathrm{~min}$ before the samples were finally cooled off at $4^{\circ} \mathrm{C}$. A negative control with template DNA replaced by water, was performed for each set of amplifications, in order to verify the absence of contamination.

Aliquots of PCR products were run in a $1 \%$ Agarose $(3 \mathrm{v} / \mathrm{cm})$ gel using a TAE $1 \mathrm{X}$ buffer. Invitrogen DNA Ladder (100 pb) was used as a molecular weight marker. Gels were stained with Ethidium Bromide and documented under UV light (Master image VDS).

Selection of primers: In a pilot survey, 36 different 10base primers (Operon kits $\mathrm{A}, \mathrm{H}$ and $\mathrm{P}$ ) were evaluated (Operon Technologies Inc., Alameda, CA, USA), of which six primers gave clear, reproducible, informative marker patterns, coded by 126 loci and these were selected to the present study (Table 2). The size of fragments was estimated by comparison with the 100 pb DNA Ladder. Band fragments with identical molecular size (same fragment) were scored for presence (1) and absence (0), generating a matrix of RAPD phenotypes, as described in literature (Exadactylos, 1997; Exadactylos et al., 2003).

Statistical data analysis: Despite the possibility of underestimating or overestimating genetic diversity (heterozygotes are undetected and band frequencies are below 50\%), RAPD provides useful estimates of genetic variation allowing for plausible assumptions (Kimberling et al., 1996; Exadactylos et al., 2003). The assumptions adopted in the present work about RAPD profiles in $C$. monoculus (Tucunaré) are: all RAPD loci showed complete dominance and the absence of a band indicated the genotype of a homozygote for the recessive allele $\left(\mathrm{q}^{2}\right)$; all loci had 2 alleles with frequencies $\mathrm{p}$ and $\mathrm{q}$ and only one allele amplified to produce a band; polymorphic bands segregated in a Mendelian fashion and all populations are under Hardy-Weinberg equilibrium $\left(\mathrm{p}^{2}+2 \mathrm{pq}+\mathrm{q}^{2}=1\right.$, or $\left.\mathrm{p}+\mathrm{q}=1\right)$ (Lynch and Milligan, 1994) and the calculated genetic diversity represents that expected under Hardy-Weinberg equilibrium.

Genetic diversity index of Nei (1972) was used to determine genetic variability between populations. Number of migrants per generation $(\mathrm{Nm})$ was used to determine the gene flow between populations.

Genetic divergence was analyzed according to the genetic distance index also proposed by Nei (1972). 
Am. J. Environ. Sci., 8 (1): 35-41, 2012

The method of cluster analysis was UPGMA (Unweighted Pair-Group Method Using an Arithmetic Average) with the fit of the dendrograms assessed by goodness of fit statistics. The genetic distance dendrogram (or phenogram) was constructed to graphically represent the divergence pattern between populations occurring in the different lakes. The analyses were performed using the Program TFPGA 1.3 (Miller, 1997).

\section{RESULTS}

Estimated allele frequencies using RAPD encoding loci varied between populations of tucunaré. The populations from two lakes (Preto and Campina) presented higher percentage of Polymorphic Loci (PL) than the populations of the other five studied lakes (Table 3). From the total 126 loci, 32 were polymorphic in all seven populations (22.56\% of analyzed loci). The mean Observed Heterozigosity (HO) was lower than the mean Expected Heterozigosity $(\mathrm{HE})(\mathrm{HO}<\mathrm{HE})$ for all populations from the seven lakes (Table 3 ).

The analysis of the 32 RAPD polymorphic loci suggests a high genetic structure among the populations $(\Phi s t=0.2623)$ and that the genetic structure inside the populations is $73.77 \%$ (Table 4). Gene flow among populations indicates that a low rate of migrants increase isolations of the populations of tucunare in the lakes $(\mathrm{Nm}=0.7025)$.

Comparisons among the populations of different lakes by the Genetic Distance (and Identity) Matrix show that the most similar populations (genetically) are the ones between Baixio and Petro lakes (Table 5); while the most distant populations occur between the populations of Baixio Lake and Maraca Lake. In fact, according to the cluster analysis, populations from lakes Maraca, Poraque and Campina form a separate group of specimens when compared to the populations from lakes Baixio, Preto, Iauara and Anana (Fig. 2). Maraca, Poraque and Campina populations are closely related; so are the populations of the other four lakes.

Table 3: Genetic variability for the RAPD 32 polymorphic loci on tucunare populations from the seven lakes in the CoariManaus course. Expected $\left(\mathrm{H}_{\varepsilon}\right)$ and Observed Heterozigocity $\left(\mathrm{H}_{\mathrm{O}}\right)$, Population Sample $(\mathrm{N})$, Polymorphic Loci Number (PLN) and Polymorphic Loci Percentage (\%PL)

\begin{tabular}{lllrcr}
\hline Population & $\mathrm{H}_{\varepsilon}$ & $\mathrm{H}_{\mathrm{O}}$ & $\mathrm{N}$ & $\mathrm{PLN}$ & \multicolumn{1}{c}{$\%$ PL } \\
\hline Baixio & 0.0337 & 0.0303 & 5 & 2 & 8.7302 \\
Preto & 0.1354 & 0.1308 & 15 & 8 & 39.6825 \\
Iauara & 0.0436 & 0.0360 & 3 & 2 & 11.1111 \\
Ananá & 0.0825 & 0.0747 & 6 & 4 & 20.6349 \\
Campina & 0.1458 & 0.1410 & 16 & 8 & 38.8889 \\
Maracá & 0.1021 & 0.0948 & 8 & 6 & 29.3651 \\
Poraquê & 0.0340 & 0.0306 & 5 & 2 & 9.5238 \\
Total & - & - & 57 & 32 & 22.5624 \\
\hline
\end{tabular}

Table 4: Statistic $\Phi$ ( $\Phi$ st and 1 - $\Phi$ st) and the number of migrants for each generation $(\mathrm{Nm})$ of the seven tucunare natural populations in Coari-Manaus course

\begin{tabular}{llll}
\hline & $\Phi S t$ & $1-\Phi$ st & Nm \\
\hline All loci & 0.2623 & 0.7377 & 0.7025 \\
Upper (IC 95\%)* & 0.3085 & 0.6915 & \\
Lower (IC 95\%)* & 0.2110 & 0.7890 & \\
\hline
\end{tabular}

Table 5: Genetic distance (above the diagonal) and identity (below the diagonal) matrix comparisons among populations of Cichla monoculus from the seven studied lakes of Solimoes River (Amazonas, Brazil)

\begin{tabular}{llllllll}
\hline Population & Baixio & Preto & Iauara & Ananá & Campina & Maracá & Poraquê \\
\hline Baixio & - & 0.0264 & 0.0652 & 0.0578 & 0.0634 & 0.0776 & 0.0525 \\
Preto & 0.9739 & - & 0.0523 & 0.0469 & 0.0492 & 0.0523 & 0.0492 \\
Iauara & 0.9369 & 0.9490 & - & 0.0502 & 0.0652 & 0.0649 & 0.0538 \\
Ananá & 0.9438 & 0.9542 & 0.9510 & - & 0.0549 & 0.0640 & 0.0734 \\
Campina & 0.9386 & 0.9520 & 0.9369 & 0.9466 & - & 0.0464 & 0.0429 \\
Maracá & 0.9254 & 0.9490 & 0.9372 & 0.9380 & 0.9546 & - & 0.0302 \\
Poraquê & 0.9488 & 0.9520 & 0.9476 & 0.9292 & 0.9580 & 0.9703 & - \\
\hline
\end{tabular}

\section{DISCUSSION}

The RAPD is more sensitive in detecting genetic variation; but because they are usually dominant markers (Lynch and Milligan, 1994) more loci are needed to obtain more accuracy of estimates of genetic variability. Those analyses were enough to detect discrete differences between populations in different lakes and lead us to search for a higher number of loci to be analyzed, as the 126 loci assessed with RAPD methodology, of which, 32 presented polymorphic alleles.

The low variability presented by tucunaré populations are surprisingly similar to the results obtained by Oliveira et al. (2006) in other Cichla species from Parana River. Indeed, it should be expected low genetic variability in populations living in hydrographic basins other than the Amazon, since this genus is endemic to this basin. This genus (Cichla) has been introduced in almost all other hydrographic basins in Brazil. In the Northeast region, tucunaré is raised in small dams (named acudes) in order to provide fish protein to human population living in that area. Due to its tasteful meat, its quality meat has created a high demand for this species across the country. These exotic populations are indeed smaller in number and genetic variability. The low genetic variability found in the present work is not the expected results for a wild population living in the Amazon basin. These results suggest the analyzed populations have low effective size (low Ne) (Frankham, 1996). One cannot reject the idea of species hybridization, although the animals were all morphologically characterized as $C$. monoculus. Andrade et al. (2001), investigating mtDNA of $C$. monoculus and $C$. temensis from Amazon basin, also observed low genetic variability in both species. It is 
common that the same species mate in and between lakes, since lakes are not isolated all year long.

As C. monoculus is a non migratory species (it is in fact a territorial species), it is expected a higher structured population with low number of migrants. This conclusion is in accordance with the observations of Farias et al. (2005) that suggest non migratory species have increased probability to present miscegenation between related specimens. In consequence, there will be a reduction on the heterozygosis, loss of allelic diversity and decreased genetic variability. In addition, the endogamy can result in disomy of some recessive alleles; the adaptive value of the population will decrease in a very short time. RAPD alleles also presented lower observed heterozygosis than expected.

F statistics for RAPD markers showed that these populations are highly structured $(\Phi s t=0.2623)$. Estimated number of migrants was also low; less than 1 migrant into the average population per generation $(\mathrm{Nm}$ $=0.7025)$. These data indicate an insufficient gene flow between populations, causing an accelerated differentiation in a period of time shorter than one could expect for naturally distributed species.

Therefore, any conservation managing of these populations shall take into account the estimated low gene flow between lakes and highly structured population. Genetic drift may be taking place due to a small effective number in some of the populations studied in the present work as well as low genetic variability and highly structured population (Table 4). Further analysis with more effective markers such as microsatellites assessing each population as subpopulation or isolated population are required in order to check if there is, as suggested by the data, some fact impairing migration between lakes.

The studied region has been negatively impacted by increased human population density coupled with an increase of urban and riverside communities; a result, local environmental resources have been exploited causing damage to aquatic environments. Subsistence fisheries in this region are very common and can affect local fish populations. Commercial fisheries are an important economic activity within the studied area and consequently may be detrimental to natural populations of this species. As above mentioned, all Cichla species are widely used for commercial fishing due to local gastronomy. Sports fishing in the Amazon is another source of anthropogenic disturbance of this species. Thus, commercial and recreational fishing may have influenced the results described in this study.

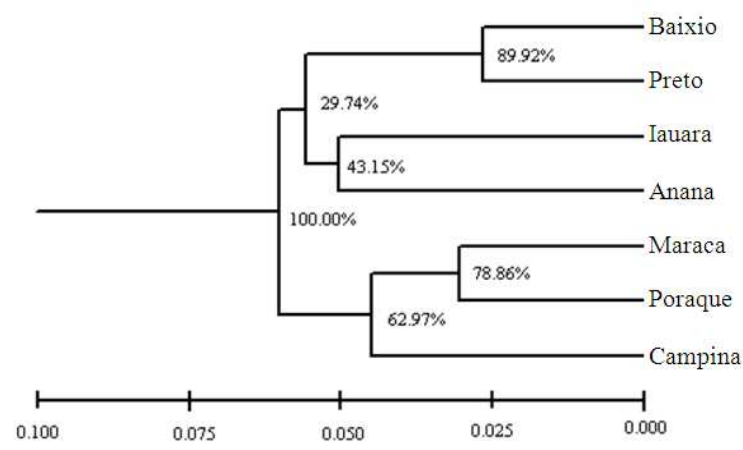

Fig. 2: Genetic structure pattern in tucunaré populations in the seven lakes of Coari-Manaus route, defined by UPGMA group, based on Jaccard's similarity index (\%) and Nei's genetic distance (1972)

C. monoculus gene flow is, as already mentioned, less than one specimen for each generation $(\mathrm{Nm}=0.7025)$. According to Pereira et al. (2007), when the gene flow is limited, populations tend to reduce their effective size and increase their endogamy, resulting in a greater probability of differentiation. To Slatkin (1985), when Nm is less or equal to 1 , population differentiation will be the outcome of genetic drift in the population. In the absence of a selective feature, genetic drift can influence the differentiation of tucunare populations in the studied lakes. The smaller the population effective size, the bigger will be the effect of the genetic drift over it (Allendorf and Luikart, 2007). In addition, the fact that Cichla is a nonmigratory species contributes to the appearance of low gene flows between more distant lakes (Fig. 1). Establishment between population differentiation related to reproductive characteristics and natural habitats; in addition to the reduction of population size in lakes due to anthropogenic sources is difficult. More numerous and accurate markers should be used before any conclusion. The best markers to access those populations, including those isolated from anthropogenic disturbance, are microsatellites, codominant and highly variable makers (non-coded DNA).

Regarding the higher genetic distances between two clusters, one can observe that they have a genetic distance between Cichla populations from eastern and western lakes (Fig. 1 and 2) suggesting a probable isolation between those populations. The non correlation of genetic with geographic distance shown by our data suggests that there is an absence of isolation-by-distance, in which case $F$ statistics is underestimating the degree of differentiation and overestimating the gene flow (Slatkin, 1985). Regarding geographic distances among all lakes, more accurate data will be necessary when considering populations in a lake by lake basis (F statistics) and 
population structure analysis of each lake. This will be possible with microsatellite markers.

Thus far, analyzing the data obtained, the populations near Manaus are showing significant genetic distance between them of 0.0447 , evidence that the reproductive isolation between Cichla specimens from Campina, Maraca and Poraque lakes is accentuated. If this slight isolation persists, specimens from Campina Lake may form a separate group of individuals from Maraca and Poraque lakes causing this population to reduce further until it loses its ability to recover variability and ultimately extinguishes. The statistics and results used may be inaccurate because unreliable estimates of population variation were derived from limited sample sizes. However, for immediate conservation programs for this species, one can affirm that populations from the seven studied lakes are in process of differentiation and should not be treated as a unique population.

\section{CONCLUSION}

Concluding, the RAPD electrophoresis techniques showed to be efficient in the evaluation of genetic variability of $C$. monoculus native populations in seven varzea lakes from Solimoes River. Data also showed that the species has low genetic variability. Furthermore, C. monoculus populations studied show genetic differences among lakes; specifically populations nearby Manaus differ from populations near the city of Coari. An immediate conservation program that regulates closure periods, minimum size capture and management of sports fishing is needed.

\section{ACKNOWLEDGEMENT}

This study was funded by a joint grant between National Research Council (CNPQ-Conselho Nacional de Desenvolvimento Científico e Tecnológico) and Amazon State Research Foundation (FAPEAMFundação de Amparo à Pesquisa do Estado do Amazonas) through the INCT Program (National Institute of Science and Technology) to ALV ProjectADAPTA (Aquatic Organisms Adaptations to their Environment). Fish has been collected during the research trips of PIATAM network, funded by FINEP and Petrobras. CHAS is the recipient of Graduate fellowship from CNPQ and CFSS was the recipient of a Graduate fellowship from FAPEAM. VMFAV and ALV is the recipient of a research fellowship from CNPQ. The authors are thankful to Pedro F. A. Val for drawing Fig. 1.

\section{REFERENCES}

Allendorf, F.W. and G. Luikart, 2007. Conservation and the Genetics of Populations. 1st Edn., John Wiley and Sons, Malden, MA., ISBN: 1405121459, pp: 642.

Andrade, F., H. Schneider, I. Farias, E. Feldberg and I. Sampaio, 2001. Análise filogenética de duas espécies simpátricas de tucunaré (Cichla, Perciformes), com registro de hibridização em diferentes pontos da bacia Amazônica. Rev. Virt. Inic. Acad. UFPA., 1: 1-11.

Calcagnotto, D. and S.D.A. Toledo-Filho, 2000. Loss of genetic variability at the transferrin locus in five hatchery stocks of tambaqui (Colossoma macropomum). Genet. Mol. Biol., 23: 127-130.

Carvajal, F., J. Nunes, F. Duponchelle and J.F. Renno, 2005. Variabilidad genetica y estructuración poblacional de Cichla monoculus en el Alto Madera (Bolivia), a partir del analisis EPIC-PCR. In: Biologia de las poblaciones de peces de la Amazonia y piscicultura, Renno, J.F., C. Garcia, F. Duponchelle and J. Nunes, J (Eds). IIAP/IRP, Iquito, pp: 111-115.

Exadactylos, A., 1997. Population of the Dover sole, Solea solea L. (Linneaus, 1758) (Teleostei: Soleidae). Ph.D. Thesis, University of Liverpool.

Exadactylos, A., A.J. Geffen, P. Panagiotaki and J.P. Thorpe, 2003. Population structure of Dover sole Solea solea: RAPD and allozyme data indicate divergence in European stocks. Mar. Ecol. Prog. Ser., 246: 253-264. DOI: 10.3354/meps 246253

Farias, I.P., W.R. Vasconcelos, M.S. Nunes, E. Mota and T. Hrbek, 2005. Padroes GeneticoPopulacionais De Peixes Da Varzea. In: Biología de las poblaciones de peces de la Amazônia y piscicultura, Renno, J.F., C. Garcia, F. Duponchelle and J. Nunes, J (Eds). IIAP/IRP, Iquito, pp: 91-95.

Frankham, R., 1996. Relationship of genetic variation to population size in wildlife. Conserv. Biol., 10: 1500-1508. DOI: $\quad 10.1046 / J .1523-$ 1739.1996.10061500.X

Jepsen, D.B., K.O. Winemiller and D.C. Taphorn, 1997. Temporal patterns of resource partitioning among Cichla species in a Venezuelan blackwater river. J. Fish Biol., 51: 1085-1108. DOI: 10.1111/J.1095-8649.1997.TB01129.X

Kimberling, D.N., A.R. Ferreira, S.M. Shuster and P. Keim, 1996. RAPD marker estimation of genetic structure among isolated northern leopard frog populations in the south-western USA. Mol. Ecol., 5: 521-529. DOI: $10.1046 / \mathrm{j} .1365-$ 294X.1996.00121.x 
Kullander, S.O. and E.J.G. Ferreira, 2006. A review of the South American cichlid genus Cichla, with descriptions of nine new species (Teleostei: Cichlidae). Ichthyol. Explor. Fres., 17: 289-398.

Lynch, M and B.G. Milligan, 1994. Analysis of population genetic structure with RAPD markers. Mol. Ecol., 3: 91-99. DOI: 10.1111/j.1365294X.1994.tb00109.x

Miller, M.P., 1997. Tools for Population Genetic analyses (TFPGA) 1.3: A Windows program for the analysis of allozyme and molecular population genetic data. Computer software distributed by author.

Nei, M., 1972. Genetic distance between populations. Am. Nat., 106: 283-292. DOI: 10.1086/282771

Nelson, J.S., 2006. Fishes of the World. 4th Edn., John Wiley and Sons, Hoboken, ISBN-10: 0471250317. pp: 601 .

Oliveira, A.V., A.J. Prioli, S.M.A.P. Prioli, T.S. Bignotto and H.F. Julio-Junior et al., 2006. Genetic diversity of invasive and native Cichla (Pisces: Perciformes) populations in Brazil with evidence of interspecific hybridization. J. Fish Biol., 69: 260-277. DOI: 10.1111/J.1095-8649.2006.01291.X

Parker, P.G., A.A. Snow, M.D. Schug, G.C. Booton and P.A. Fuerst, 1998. What molecules can tell us about populations: Choosing and using a molecular marker. Ecology, 79: 361-382. DOI: $10.2307 / 176939$

Pereira, M.D.F., F.D. Valva, A.S.G. Coelho, A.V. Aguiar and M.I. Zucchi, 2007. Estrutura genética de populaçoes de espécies arbóreas nativas do cerrado encontradas em terrenos serpentínicos genetic structure of populations of arboreal species native to serpentine soils of the cerrado. Pesquisa Agrop. Trop., 34: 75-82.
Petrere, Jr., M., 1996. Fisheries in large tropical reservoirs in South America. Lake. Reserv. Res. Manage., 2: 111-133. DOI: 10.1111/J.14401770.1996.TB00054.X

Povh, J.A., H.L.M. Moreira, R.P. Ribeiro, A.J. Prioli and L. Vargas et al., 2005. Estimativa da variabilidade genética em linhagens de tilápia do Nilo (Oreochromis niloticus) com a técnica de RAPD. Acta Scient., 27: 1-10.

Sambrook, J. and D.W. Russel, 2001. Molecular Cloning: A Laboratory Manua. 3nd Edn., CSHL Press, New York, ISBN-10: 0879695773.

Sampaio, A.M.B.D.M., F. Kubitza and J.E.P. Cyrino, 2000. Relação energia: Proteína $\mathrm{Na}$ nutrição do tucunaré. Sci. Agr., 57: 213-219.

Slatkin, M., 1985. Rare alleles as indicators of gene flow. Evolution., 39: 53-65. DOI: 10.2307/2408516

Tringali, M.D., T.M. Bert, S. Seyoum, E. Bermingham and D. Bartolacci, 1999. Molecular phylo and ecological diversification of the transisthmian fish genus Centropomus (Perciformes: Centropomidae). Mol. Phylogenet. Evol., 13: 193-207. DOI: 10.1006/mpev.1999.0624

Williams, J.G., A.R. Kubelik, K.J. Livak, J.A. Rafalski and S.V. Tingey, 1990. DNA polymorphisms amplified by arbitrary primers are useful as genetic markers. Nucleic Acids Res., 18: 6531-6535. PMID: 1979162 